\title{
Kenakalan Remaja dalam Perspektif Antropologi
}

\section{Nurhasanah Leni}

\author{
Dosen Fakultas Tarbiyah dan Keguruan, UIN Raden Intan Lampung
}

Diterima: 7 Januari 2017. Disetujui: 20 Februari 2017. Dipublikasikan: Mei 2017

\begin{abstract}
Juvenile Delinquency is a deviant behavior that occurs among adolescents. Juvenile delinquency refers to adolescent behavior that is not in accordance with the norms that live in society. In the case of juvenile delinquency misbehavior is classified into two groups relating to legal norms namely: (1) delinquency that is immoral and social and is not regulated in law so that it can not or is difficult to be classified as a violation of law; (2) delinquency in violation of law for settlement in accordance with applicable law and law is the same as unlawful conduct if committed by an adult. Furthermore, cultures or cultures derived from the Sanskrit buddhayat, which is the plural form of buddhi (mind or intellect) are defined as matters relating to the human mind and reason. In English, culture is called culture, derived from the Latin word colere, that is to process or work, so that juvenile delinquency in cultural perspective is very visible relationship. Teens should be able to get as many adults as possible who will motivate good behavior as well as those who have improved themselves after failing at this stage. The existence of motivation from family, teacher, peers is something that can be done to overcome juvenile delinquency and also good for adolescent development. Let's solve juvenile delinquency wisely. This paper is based on the results of several research researchers.
\end{abstract}

Keywords: Delinquency; Juvenile; Anthropology; Culture; Psychology

Abstrak: Kenakalan Remaja merupakan sebuah perilaku yang menyimpang yang terjadi pada kalangan remaja. Kenakalan remaja menunjuk perilaku remaja yang tidak sesuai dengan norma-norma yang hidup di dalam masyarakatnya. Dari segi hukum kenakalan remaja digolongkan dalam dua kelompok yang berkaitan dengan norma-norma hukum yaitu: (1) kenakalan yang bersifat amoral dan sosial serta tidak diatur dalam undang-undang sehingga tidak dapat atau sulit digolongkan sebagai pelanggaran hukum; (2) kenakalan yang bersifat melanggar hukum dengan penyelesaian sesuai dengan undang-undang dan hukum yang berlaku sama dengan perbuatan melanggar hukum bila dilakukan orang dewasa. Selanjutnya budaya atau kebudayaan berasal dari bahasa Sansekerta yaitu buddhayah, yang merupakan bentuk jamak dari buddhi (budi atau akal) diartikan sebagai hal-hal yang berkaitan dengan budi dan akal manusia. Dalam bahasa Inggris, kebudayaan disebut culture, yang berasal dari kata Latin Colere, yaitu mengolah atau mengerjakan, sehingga kenakalan remaja dalam perspektif kebudayaan sangat terlihat kaitannya. Remaja harus bisa mendapatkan sebanyak mungkin orang dewasa yang kiranya memotivasi perilaku yang baik dan juga orang yang telah berhasil memperbaiki diri setelah sebelumnya gagal pada tahap ini. Adanya motivasi dari keluarga, guru, teman sebaya merupakan hal yang bisa dilakukan untuk mengatasi kenakalan remaja dan juga berpengaruh baik untuk perkembangan remaja. Marilah kita tanggulangi kenakalan remaja dengan bijak. Tulisan ini berdasarkan hasil penelitian beberapa orang peneliti.

Kata Kunci: Kenakalan; Remaja; Antropologi; Kebudayaan; Psikologi

\section{Pendahuluan}

Perkembangan remaja pada masa sekarang ini banyak yang sudah tidak patut dibanggakan lagi. Saat ini sulit sekali mengatasi perilaku kenakalan remaja. Akhir-akhir ini 
sering kita amati berita di televisi maupun radio akibat perilaku kenakalan remaja diantaranya tawuran, pelecehan seksual yang telah banyak dilakukan oleh kalangan pelajar, pemakaian obatobat terlarang seperti narkoba dan lain sebagainya. Kehidupan yang terjadi pada remaja pada saat ini sangat memprihatinkan. Remaja yang semestinya menjadi bibit-bibit penerus bangsa saat ini tidak bisa lagi menjadi harapan untuk kemajuan bangsa dan negara. Bahkan perilaku mereka saat ini cenderung menurun. Sangat disayangkan para remaja saat ini dengan sangat mudah melakukan perubahan sosial dan budaya dengan meniru budaya luar tanpa adanya filter. Banyak tayangan di televisi pada saat ini yang tidak bernilai edukatif sehingga meningkatkan kenakalan remaja. Hal ini disebabkan karena industri perfilman kurang memberikan pesan-pesan moral terhadap siaran yang ditampilkan. Seperti sinetron-sinetron maupun reality show yang banyak menayangkan tentang pergaulan bebas remaja bersifat pornografis, kekerasan, hedonisme selalu ditampilkan di layar kaca, Seperti tayangan remaja dalam mengonsumsi obat-obatan terlarang, cara berpakaian yang terlalu minim dan lain sebagainya. Inilah yang seringkali menjadi contoh tidak baik yang sering mempengaruhi remaja-remaja yang berada di kota maupun di daerah untuk mengikuti perilaku tersebut.

Kenakalan remaja dalam studi masalah sosial termasuk ke dalam perilaku menyimpang. Penggunaan konsep perilaku menyimpang secara tersirat mengandung makna bahwa ada aturan yang harus ditempuh. Perilaku yang tidak melalui aturan tersebut berarti telah menyimpang. Masalah sosial perilaku menyimpang dibahas melalui pendekatan individual dan pendekatan sistem. Dalam pendekatan individual melalui pandangan sosialisasi. Berdasarkan pengamatan sosialisasi, perilaku akan diidentifikasi sebagai masalah sosial apabila ia tidak berhasil dalam bersosialisasi. Mengenai perilaku disorder di kalangan anak dan remaja membuat pengaruh negatif. Kauffman mengemukakan bahwa perilaku menyimpang juga dapat dilihat sebagai perwujudan dari konteks sosial. Perilaku disorder tidak dapat dilihat secara sederhana sebagai tindakan yang tidak layak, melainkan lebih dari itu harus dilihat sebagai hasil interaksi dari transaksi yang tidak benar antara seseorang dengan lingkungan sosialnya.

Mengenai pendekatan sistem, yaitu perilaku individu sebagai masalah sosial yang bersumber dari sistem sosial. Dikatakan Eitzen, bahwa seseorang dapat menjadi buruk/jelek oleh karena hidup dalam lingkungan masyarakat yang buruk. Hal ini dapat dijelaskan bahwa pada umumnya masyarakat yang mengalami gejala disorganisasi sosial, norma dan nilai sosial menjadi lemah, sehingga memungkinkan terjadinya berbagai bentuk penyimpangan perilaku. Dalam jangka waktu kurang dari dekade terakhir, kenakalan remaja semakin amat memprihatinkan. Kenakalan remaja diartikan sebagai suatu outcome dari suatu proses yang menunjukkan penyimpangan tingkah laku atau pelanggaran terhadap norma-norma yang ada. Kenakalan remaja disebabkan oleh berbagai faktor baik faktor pribadi, faktor keluarga yang merupakan lingkungan utama, maupun faktor lingkungan sekitar yang secara potensial dapat membentuk perilaku seorang anak.

Berdasarkan beberapa hasil penelitian ditemukan bahwa salah satu faktor penyebab timbulnya kenakalan remaja adalah tidak berperannya orangtua sebagai figur tauladan bagi anak dalam kehidupan sehari-hari. Selain itu aktivitas keluarga yang dirasa tidak aman dan tidak menyenangkan dapat menimbulkan bahaya psikologis bagi setiap usia terutama pada masa remaja. Menurut Hirschi orangtua dari remaja nakal cenderung memiliki aspirasi yang minim mengenai anak-anaknya, menghindari keterlibatan keluarga dan kurangnya bimbingan orangtua terhadap remaja. Sebaliknya, suasana keluarga yang menimbulkan rasa aman dan menyenangkan akan menumbuhkan kepribadian yang wajar dan begitu pula sebaliknya. 
Kenakalan remaja menunjuk perilaku remaja yang tidak sesuai dengan norma-norma yang hidup di dalam masyarakatnya. Remaja yang nakal itu disebut pula sebagai anak cacat sosial. Mereka menderita cacat mental disebabkan oleh pengaruh sosial yang ada ditengah masyarakat, sehingga perilaku mereka dinilai oleh masyarakat sebagai suatu kelainan dan disebut "kenakalan". Dalam Bakolak inpres no: 6/1977 buku pedoman 8, dikatakan bahwa kenakalan remaja adalah kelainan tingkah laku/tindakan remaja yang bersifat anti sosial, melanggar norma sosial, agama serta ketentuan hukum yang berlaku dalam masyarakat.

Dari segi hukum kenakalan remaja digolongkan dalam dua kelompok yang berkaitan dengan norma-norma hukum yaitu: (1) kenakalan yang bersifat amoral dan sosial serta tidak diatur dalam undang-undang sehingga tidak dapat atau sulit digolongkan sebagai pelanggaran hukum; (2) kenakalan yang bersifat melanggar hukum dengan penyelesaian sesuai dengan undang-undang dan hukum yang berlaku sama dengan perbuatan melanggar hukum bila dilakukan orang dewasa. Menurut bentuknya, kenakalan remaja dibagi ke dalam tiga tingkatan: (1) kenakalan biasa, seperti suka berkelahi, suka keluyuran, membolos sekolah, pergi dari rumah tanpa pamit, (2) kenakalan yang menjurus pada pelanggaran dan kejahatan seperti mengendarai mobil tanpa SIM, mengambil barang orang tua tanpa izin, (3) kenakalan khusus seperti penyalahgunaan narkotika, hubungan seks di luar nikah, pemerkosaan dan lain-lain. Kategori di atas yang dijadikan ukuran kenakalan remaja dalam penelitian.

Tentang normal tidaknya perilaku kenakalan atau perilaku menyimpang, pernah dijelaskan dalam pemikiran Emile Durkheim. Bahwa perilaku menyimpang atau jahat kalau dalam batas-batas tertentu dianggap sebagai fakta sosial yang normal dalam bukunya " Rules of Sociological Method" dalam batas-batas tertentu kenakalan adalah normal karena tidak mungkin menghapusnya secara tuntas, dengan demikian perilaku dikatakan normal sejauh perilaku tersebut tidak menimbulkan keresahan dalam masyarakat, perilaku tersebut terjadi dalam batasbatas tertentu dan melihat pada sesuatu perbuatan yang tidak disengaja.

\section{Metode Penelitian}

Metode penelitian ini dilakukan dengan deskriptif kualitatif. Biasanya dalam penelitian antropologi menggunakan penelitian lapangan (observasi langsung), namun dalam tulisan ini menggunakan studi pustaka atau menggali data dari library research untuk memperkaya khasanah keilmuan antropologi.

\section{Hasil dan Pembahasan} adalah.

Hasil dari penelitian ini adalah, solusi dalam mengatasi kenakalan remaja, di antaranya

1. Kegagalan yang mencapai identitas peran dan lemahnya kontrol diri bisa dicegah atau diatasi dengan prinsip keteladana.

2. Adanya motifasi dari keluarga, guru, teman sebaya untuk melakukan point pertama.

3. Kemauan orang tua untuk membenahi kondisi keluarga sehingga tercipta keluarga yang harmonis, komunikatif, dan nyaman bagi remaja.

4. Remaja pandai memilih teman dan lingkungan yang baik serta orang tua

5. Memberi arahan dengan siapa dan dikomunitas mana remaja harus bergaul.

6. Remaja membentuk ketahanan diri agar tidak terpengaruh jika ternyata teman sebaya atau komunitas yang ada tidak sesuai dengan harapan.

A. Penyebab Kenakalan Remaja 
Perilaku nakal remaja biasa disebabkan oleh faktor dari remaja itu sendiri (internal) maupun dari luar (eksternal)

1. Faktor Internal (intern)

Faktor internal (intern) adalah faktor yang datangnya dari dalam tubuh remaja sendiri. Faktor internal ini jika mendapatkan contoh-contoh yang kurang mendidik dari tayangan televisi akan menimbulkan niat remaja untuk meniru adegan-adegan yang disaksikan pada isi program televisi tersebut. Timbulnya minat atau kesenangan remaja yang memang gemar menonton acara televisi tersebut dikarenakan kondisi remaja yang masih dalam tahap pubertas. Dengan demikian rasa ingin tahu untuk mencontoh berbagai tayangan tersebut yang dinilai kurang memberikan nilai moral bagi perkembangan remaja membuat mereka tertarik.

2. Faktor Eksternal (ekstern)

Faktor eksternal (ekstern) adalah faktor yang datangnya dari luar tubuh remaja. Faktor ini dapat disebut sebagai faktor lingkungan yang memberikan contoh atau teladan negatif serta didukung pula oleh lingkungan yang memberikan kesempatan. Yang telah banyak teradopsi oleh nilai-nilai budaya luar yang kurang dapat mereka seleksi mana yang layak dan yang tidak layak untuk ditiru.

3. Kurangnya perhatian

Dari orang tua dan lingkungan yang memang menyediakan pergaulan buruk, maka memberikan dampak buruk pula bagi remaja untuk mudah larut dalam hal-hal negatif, sehingga akhirnya ketergantungan dan mereka terus melakukannya berulang kali seperti halnya biasa dan membentuk sebuah budaya yang tak bisa lepas dari hidup mereka. Dampak dari kegiatan tersebut akan menciptakan orang-orang yang hedonis.

\section{B. Keberfungsian Sosial}

Istilah keberfungsian sosial mengacu pada cara-cara yang dipakai oleh individu akan kolektivitas seperti keluarga dalam bertingkah laku agar dapat melaksanakan tugas-tugas kehidupannya serta dapat memenuhi kebutuhannya. Penampilan dianggap efektif diantarannya jika suatu keluarga mampu melaksanakan tugas-tugasnya. Keberfungsian sosial adalah kemampuan seseorang dalam melaksanakan tugas dan peranannya selama berinteraksi dalam situasi sosial tertentu berupa adanya rintangan dan hambatan dalam mewujudkan nilai dirinya mencapai kebutuhan hidupnya.

Keberfungsian sosial kelurga mengandung pengertian pertukaran dan kesinambungan, serta adaptasi resiprokal antara keluarga dengan anggotannya, dan dengan lingkungannya, serta dengan tetangganya, dan lain-lain. Kemampuan berfungsi sosial secara positif dan adaptif bagi sebuah keluarga salah satunya jika berhasil dalam melaksanakan tugas-tugas kehidupan, peranan dan fungsinya terutama dalam sosialisasi terhadap anggota keluarganya.

\section{Hubungan Kebudayaan Dengan Masyarakat}

Kebudayaan sangat erat hubungannya dengan masyarakat. Cultural determinism: segala sesuatu yang terdapat dalam masyarakat ditentukan oleh kebudayaan yang dimiliki oleh masyarakat itu sendiri. Budaya atau kebudayaan berasal dari bahasa Sansekerta yaitu buddhayah, yang merupakan bentuk jamak dari buddhi (budi atau akal) diartikan sebagai hal-hal yang berkaitan dengan budi dan akal manusia. Dalam bahasa Inggris, kebudayaan disebut culture, yang berasal dari kata Latin colere, yaitu mengolah atau mengerjakan. 
Menurut Andreas Eppink, kebudayaan mengandung keseluruhan pengertian, nilai, norma, ilmu pengetahuan serta keseluruhan struktur-struktur sosial, religius, dan lain-lain, juga segala pernyataan intelektual dan artistik yang menjadi ciri khas suatu masyarakat.

Menurut Edward B. Tylor, kebudayaan merupakan keseluruhan yang kompleks, yang di dalamnya terkandung pengetahuan, kepercayaan, kesenian, moral, hukum, adat istiadat, dan kemampuan-kemampuan lain yang didapat seseorang sebagai anggota masyarakat. Sifat hakikat kebudayaan sebagai berikut: 1 . Kebudayaan terwujud dan tersalurkan lewat perilaku manusia; 2. Kebudayaan telah ada terlebih dahulu mendahului lahirnya suatu generasi tertentu dan tidak akan mati dengan habisnya usia generasi yang bersangkutan; 3. Kebudayaan diperlukan oleh manusia dan diwujudkan tingkah lakunya; 4. Kebudayaan mencangkup aturan-aturan yang berisikan kewajiban-kewajiban, tindakan-tindakan yang diterima dan ditolak, tindakan-tindakan yang dilarang dan tindakan-tindakan yang diizinkan

D. Korelasi Antara Kepribadian Dengan Kebudayaan

Pengertian masyarakat menunjuk pada sejumlah manusia, sedangkan pengertian kebudayaan menunjuk pada pola-pola perilaku yang khas dari masyarakat tersebut. Masyarakat dan kebudayaan sebenarnya merupakan perwujudan atau abstraksi perilaku manusia. Menurut Theodore M. Newcomb, yaitu bahwa kepribadian merupakan organisasi sikap-sikap (predispositions) yang dimiliki seseorang sebagai latar belakang terhadap perilaku.

\section{E. Fase Remaja}

Fase remaja merupakan masa dimana seorang individu mengalami peralihan dari satu tahap ke tahap berikutnya dan mengalami perubahan baik emosi, tubuh, minat, pola perilaku, dan juga penuh dengan masalah-masalah. Oleh karenanya, remaja sangat rentan sekali mengalami masalah psikososial, yakni masalah psikis atau kejiwaan yang timbul sebagai akibat terjadinya perubahan sosial. Namun satu hal yang pasti, konflik yang dihadapi oleh remaja semakin kompleks seiring dengan perubahan pada berbagai dimensi kehidupan dalam diri mereka. Untuk dapat memahami remaja, maka perlu dilihat berdasarkan perubahan pada dimensi-dimensi tersebut.

1. Dimensi Biologis

Pada saat seorang anak memasuki fase pubertas yang ditandai dengan menstruasi pertama pada remaja putri atau pun perubahan suara pada remaja putra, secara biologis dia mengalami perubahan yang sangat besar. Pubertas menjadikan seorang anak tiba-tiba memiliki kemampuan untuk ber-reproduksi. Pada fase pubertas, hormon seseorang menjadi aktif dalam memproduksi dua jenis hormon (gonadotrophins atau gonadotrophic hormones) yang berhubungan dengan pertumbuhan, yaitu:

- Follicle-Stimulating Hormone (FSH)

- Luteinizing Hormone (LH)

2. Dimensi Kognitif

Perkembangan kognitif remaja, dalam pandangan Jean Piaget (seorang ahli perkembangan kognitif) merupakan periode terakhir dan tertinggi dalam fase pertumbuhan operasi formal (period of formal operations). Pada fase ini, idealnya para remaja sudah memiliki pola pikir sendiri dalam usaha memecahkan masalah-masalah yang kompleks dan abstrak.

3. Dimensi Moral

Para remaja mulai membuat penilaian tersendiri dalam menghadapi masalah-masalah populer yang berkenaan dengan lingkungan mereka, misalnya: politik, kemanusiaan, perang, 
keadaan sosial, dsb. Remaja tidak lagi menerima hasil pemikiran yang kaku, sederhana, dan absolut yang diberikan pada mereka selama ini tanpa bantahan. Remaja mulai mempertanyakan keabsahan pemikiran yang ada dan mempertimbangan lebih banyak alternatif lainnya.

4. Dimensi Psikologis

Masa remaja merupakan masa yang penuh gejolak. Pada masa ini mood (suasana hati) bisa berubah dengan sangat cepat. Remaja rata-rata memerlukan hanya 45 menit untuk berubah dari mood "senang luar biasa" ke "sedih luar biasa", sementara orang dewasa memerlukan beberapa jam untuk hal yang sama. Perubahan mood (swing) yang drastis pada para remaja ini seringkali dikarenakan beban pekerjaan rumah, pekerjaan sekolah, atau kegiatan ehari-hari di rumah. Anggapan remaja bahwa mereka selalu diperhatikan oleh orang lain kemudian menjadi tidak berdasar. Perilaku yang mengundang resiko pada masa remaja misalnya seperti penggunaan alcohol, tembakau dan zat lainnya; aktivitas social yang berganti - ganti pasangan dan perilaku menentang bahaya seperti balapan, selancar udara, dan layang gantung. Alasan perilaku yang mengundang resiko adalah bermacam - macam dan berhubungan dengan dinamika phobia balik (conterphobic dynamic), rasa takut dianggap tidak cakap, perlu untuk menegaskan identitas maskulin dan dinamika kelompok seperti tekanan teman sebaya.

\section{F. Masalah Pergaulan Bebas Pria-Wanita}

1. Arti Pergaulan Bebas

Manusia dapat bergaul bebas akan tetapi dalam suatu ke-terikatan sosial. Manusia hidup dalam keterikatan tanggung-jawab atas kesejahteraan sosial. Juga pemuda-pemudi dapat bergaul dengan bebas, tetapi tidak boleh mengabaikan tanggungjawab sosial.

Dalam pergaulan bebas, bergaul dengan siapa saja, di mana saja dan kapan saja, selalu perlu diingat:

a. Tanggung jawab atas kesejahteraan sesama manusia.

b. Menghormati hak-hak dan harga diri wanita dan pria.

c. Berpegang teguh pada norma sosial, nilai-nilai moral dan tata susila, dan norma hukum. Pergaulan bebas antara pria dan wanita dapat menjadi pergaulan yang tidak bebas lagi. Pada suatu saat pergaulannya menyempit dan hanya meliputi dua orang saja, seorang pemuda dan seorang pemudi. Pergaulan bebas berarti pergaulan yang luas antara banyak pemuda dan pemudi. Tidak terlalu menekankan pengelompokkan yang kompak antara dua orang saja, akan tetapi antara banyak muda-mudi. Pergaulan yang sudah terbatas antara dua muda-mudi akan berarti adanya suatu kekhususan, sehingga orang mengatakan bahwa kedua muda mudi ini berpacaran.

2. Mengenali Gejolak Remaja.

Menasihati remaja tidak semudah menasihati anak-anak. Mereka bukan lagi anak TK atau SD yang bisa duduk manis ketika orang tua berbicara. Usia remaja, yang dimulai sekitar 14 tahun, adalah usia di mana manusia mengalami begitu banvak perubahan baik pada organ tubuhnva maupun pada aspek psikologisnya. Mereka yang awalnva anak-anak, kemudian masuk periode puber, disusul ke periode sclanjutnya, di mana hormon sangat memengaruhi fisik dan psikisnya, cenderung mengalami beragam gejolak temperamen. Ada yang saat anak-anak pendiam, mendadak menjadi cerewet dan pandai bergaul ketika remaja. Atau kebalikannya, berubah jadi pendiam dan pemalu, padahal waktu anak-anak dulu ia sangat pandai bergaul. Sebabnya memang sejak usia puber, seorang anak akan terus mengalami perubahan karakter. Kondisi ini memhuat orang tua agak kehingungan menghadapinva sebab sifat mereka berubahubah sesuai mood. Mencoba menasihati mereka artinya mesti pandai-pandai membaca "medan 
perang", mengatur strategi agar tidak terjadi kesalahpahaman. Sebab, kalau sudah salah paham, bukannva komunikasi yang baik yang terjalin melainkan pertengkaran. Lebih baik kita tnengenali dulu seperti apa perilaku anak remaja yang berusia serba nanggung ini: dibilang anakanak, sudah tidak pantas, dibilang dewasa pun belum. Remaja awal ini biasanya akan memiliki ciri-ciri sebagai berikut:

3. Cemas Dengan Perkembangan Fisik

Pada perkembangan fisik Anak akan mengalami kecemasan, karena mengalami perubahan fisik yang mencolok, yakni tumbuh jakun, bulu-bulu di seluruh tubuh, juga kumis, dan mengalami mimpi basah. Suara pun ikut berubah, menjadi "sember". Ini semua akibat mulai dominannya hormon testoteron.Sedangkan pada anak perempuan, menstruasi mulai makin teratur, kadang disertai nyeri dan posing. Buah dada makin membesar. Semua perubahan itu membuatnya cemas, takut diketahui oleh teman lain, dijauhi, dan jadi risih sendiri.

\section{Rangsangan Libido}

Rangsangan nafsu seks (libido) yang meningkat diakibatkan adanya gejolak hormon. Ada dua jenis respon, yaitu menjadi sangat reaktif, atau justru malu, dan menyembunyikannya. Baru mendengar cerita sedikit menyerempet ke arah seks saja, sudah heboh dan penasaran sekali. Sebagian remaja justru sudah sangat male sekali ketika bertatapan dengan lawan jenis.Tiap anak memiliki respon berbeda-beda, juga berubah-ubah. Di usia ini, libido mereka juga bergejolak, mudah terangsang oleh sedikit saja hal-hal berbau seks. Inilah mengapa orang tua perk memberi dasar moral, etika, dan agama, sebab tanpa dasar itu anak cenderung mudah tergoda. Orientasi seks mulai terbentuk. Jika tak diarahkan dengan benar oleh orang tua, dapat terjadi kasus di mana anak menjadi gay atau lesbian, bahkan biseks.

\section{Mempermasalahkan Penampilan}

Akibat perubahan fisik itu, remaja belia ini jadi pusing dengan penampilannya. Ada yang berusaha menutupi perubahan-perubahan tadi, ada juga yang justru ingin menonjolkannya karena bangga dan merasa berbeda dengan teman lain yang belum mengalami. Maka jangan heran kalau mereka jadi sangat peduli pada penampilan, berlama-lama di depan cermin, mengunci diri di kamar, rajin ke salon, dan berbelanja baju-baju modis.

Jika kita melihat pertumbuhan fisik muda-mudi, maka kita mendapat bahwa mereka mengalami pertumbuhan tinggi badan yang hebat. Muda-mudi, tidak hanya menyamai tinggi badan orangtua mereka, bahkan melebihinya. Kaum remaja secara badani sudah kelihatan dewasa dan ingin menyamai per-buatan-perbuatan orang dewasa. Juga pengaruh bacaan, majalah, buku roman dan film menyebabkan muda-mudi meniru cara-cara tingkah laku dan komunikasi yang dapat mereka tiru dengan mudah. Yang paling mudah ditiru justru "permainan cinta" yang banyak di ambil sebagai inti daripada film. Puncak peniruan ini terlihat dalam pergaulan antar muda-mudi yakni pacaran. Faktor yang mempengaruhi remaja ingin berpacaran: Umur Para muda-mudi yang terlibat dalam pacaran, Sifat pacaran dan Tingkat derajat pacaran.

\section{Usia}

Faktor yang pertama yaitu usia penting sekali. Makin lanjut usia pemuda-pemudi, diharapkan mereka juga lebih memperlihatkan kematangan. Taraf kematangan ini perlu supaya mereka dapat mempertimbangkan dengan baik sifat dan tingkat pacaran dalam hubungannya dengan batas-batas kesopanan. Makin muda usianya, makin sulit mempertimbangkan batas-batas kesopanan dan pembagian waktu. Sering terlihat murid-murid SMP sudah mulai bergaul terlalu 
rapat dengan seorang kawan lain jenis. Ia juga bergaul terlalu dekat dengan teman sejenis. Pergaulan yang terlalu dekat dengan lawan jenisnya dan pertemuan yang terlalu sering dengan teman sejenisnya, mengobrol dan bermain musik tanpa batas waktu, akhirnya menye-babkan prestasi di sekolah menurun. Rapor dengan angka-angka merah menyebabkan "pergaulan anak" atau "pacaran" yang disalahkan.

Dari contoh ini jelaslah bahwa usia yang terlalu muda menyebabkan para muda-mudi kurang mampu dalam membatasi kesenangan diri, kurang dapat membatasi diri dalam pembagian waktu belajar dan rekreasi. Mereka lebih mengutamakan rekreasi dan berkumpul dengan kawan-kawannya, akhirnya tugas belajar terdesak dan kurang mendapat perhatian. Pemuda-pemudi yang sudah lebih dewasa dan masih belum belajar membatasi diri dengan pembagian waktu yang ketat akan mengalami kegagalan di sekolah. Dengan demikian umur yang memberi kematangan untuk bisa mempertimbangkan sesuatu, harus disertai pendisiplinan diri dalam hal waktu belajar, bekerja dan rekreasi serta dalam pembagian yang tepat antara tugas dan pergaulan.

\section{Sifat pacaran}

Pacaran adalah salah satu penyebab pergaulan bebas. Mungkin saja muda-mudi yang pulang dari sekolah dan searah perjalanannya ke rumah masing-masing, kalau pulang bersama maka sudah dikatakan pacaran. Belajar dan studi bersama, sudah menimbulkan kekhawatiran pada orangtua karena sudah terbayang suatu "pernikahan". Padahal pergaulan ini, sebetulnya hanva merupakan persahabatan atau perkenalan yang lebih sedikit daripada yang biasa. Sebetulnya pergaulan demi usaha mengenal lebih mendalam perlu untuk menambah pengetahuan tentang pribadi-pribadi yang akan dihadapi kelak di masa dewasa.

\section{Tingkat pacaran}

Perasaan yang mulai timbul dengan pacaran diumpamakan dengan muatan listrik, maka jarak antara kedua individu yang sedang mengalaminya akan menentukan tingkat pacaran itu. Makin dekat, makin besar kemungkinan persentuhan yang dapat menimbulkan "kortsluiting" ataupun aliran listrik yang memberi percikan bunga-api cinta. Dengan demikian muda-mudi, kaum dewasa muda yang masih jauh daripada kesanggupan membentuk keluarga, sebaiknya sangat berhati-hati dengan "main api cinta". Perlu selalu mengingat jarak yang harus dipertahankan demi "keamanan" kedua pihak. Lebih baik waspada terus demi ketenteraman hati. Sering-kali mereka yang membanggakan kekuatan hati nurani, akhirnya "terbakar" dan jatuh karena kelengahan sesaat. Dalam suasana pacaran kewaspadaan harus diperketat dan iman harus diperkuat demi menjauhkan diri dari godaan dan gangguan yang mudah timbul dan demi tercapainya cita-cita yang mulia.

\section{G. Kecanduan Narkotika Pada Remaja}

Remaja mulai mengenal narkotika dalam usia yang semakin dini. Penelitian menunjukkan bahwa saat anak-anak memasuki kelas 8, hampir 35 persen telah mencoba narkotika. Jumlah para remaja yang kecanduan narkotika adalah 20 persen dan itu adalah jumlah yang terlalu besar! Para remaja lebih rentan kecanduan narkotika karena kondisi hidup mereka. Banyak remaja kewalahan menghadapi masalah hidupnya sehari-hari. Banyak remaja memiliki rasa percaya diri yang rendah, merasa cemas, ketidakmampuan untuk mengungkapkan perasaan, dan kurang dapat mengendalikan hidup mereka. Semua hal itu sangat berkonstribusi terhadap

penggunaan narkotika dan akhirnya membuat mereka kecanduan narkotika. Narkotika 
membunuh rasa sakit kehidupan duniawi. Narkotika menghilangkan sakit fisik dan emosional dengan merubah persepsi pecandu terhadap kenyataan. Narkotika membuat pecandu kebal terhadap rasa sakit, keputus-asaan atau kesepian yang mereka rasakan di kehidupan.

Berikut ini adalah tanda-tanda umum remaja anda kecanduan narkotika:

- Perubahan dramatis terhadap sikap dan perilaku

- Muram, mata berkaca-kaca

- Sering merasa kelelahan

- Kegagalan di sekolah

- Berbohong atau mencuri

- Mengisolasi diri atau kehilangan minat untuk beraktivitas

Seringkali orang-orang terdekat dengan anak remaja anda (dalam hal ini adalah anda) lebih mudah mengingkari bahwa anak remaja mereka mempunyai masalah dengan narkotika. Namun ketika hal ini menyangkut tentang ketergantungan narkotika pada anak remaja, anda tidak dapat melakukan ini. Sangatlah penting untuk menolong mereka secepat mungkin. Jangan menyerah dan berkecil hati jika usaha awal anda gagal. Pada akhirnya anda akan dapat melaluinya dan kemudian anda dan anak remaja anda bisa berusaha memulai untuk melawan ketergantungan obat bersama-sama.

\section{H. Pornografi}

Rasa ingin tahu ditambah besarnya gairah syahwat pada masa remaja membuat banyak remaja (terutama laki-laki) terperosok ke maksiat satu ini. Banyak media yang memuat pornografi. Mulai dari poster, majalah, buku, sampai VCD. Bahkan majalah Playboy yang udah masyhur kepornoannya pun udah masuk ke Indonesia setelah majalah porno lainnya eksis di negeri ini.Menahan pandangan dari lawan jenis termasuk juga nggak liat hal-hal yang porno semacam ini. Pornografi juga memancing kejahatan seperti pelecehan seksual dan pemerkosaan. Berapa banyak kasus perkosaan berawal dari nonton VCD porno.

\section{Onani/Masturbasi}

Perilaku yang satu ini juga terkenal banget dilakukan oleh para remaja. Sebabnya ratarata sama, ingin tahu dan besarnya nafsu seksual pada masa remaja. Menurut penelitian, aktivitas ini lebih banyak dilakukan remaja pria (sekitar 90\%), namun ada juga remaja perempuan yang melakukannya (30\%). Sebagian orang menganggap melepaskan syahwat dengan onani/ masturbasi merupakan jalan yang lebih selamat daripada berzina. Kadar maksiat mungkin memang lebih rendah dari zina beneran. Tapi bukan berarti onani nggak terlarang. Dalam Islam, melampiaskan nafsu syahwat hanya diperkenankan dilakukan terhadap istri atau suami. Barangsiapa yang mencari pelampiasan selain itu maka mereka termasuk orang yang melampaui batas. Onani jelas termasuk jalan lain, berarti onani termasuk perbuatan melampaui batas.

Barangsiapa yang mencari pelampiasan selain itu maka mereka termasuk orang yang melampaui batas. Onani jelas termasuk jalan lain, berarti onani termasuk perbuatan melampaui batas. Jika onani dibolehkan, tentu Rasulullah shalallahu 'alaihi wasalam nggak perlu memerintahkan para pemuda yang belum mampu untuk menikah untuk berpuasa. Mereka yang belum mampu menikah tentu tinggal diperintahkan untuk onani. Namun kenyataannya enggak, mereka yang belum mampu menikah diperintahkan untuk berpuasa, tidak diperintahkan untuk onani. Jadi, onani tetap aja terlarang.

J. Musik 
Satu hal yang biasanya remaja kurang tahu bahwa hal tersebut juga merupakan hal negatif adalah mendengarkan musik. Parahnya, kehidupan remaja saat ini kayaknya nggak bisa lepas dari musik. Konsumen musik terbanyak tetap aja remaja. Buktinya, media cetak remaja, baik yang untuk cewek atau cowok, baik yang majalah atau yang tabloid, semuanya memberikan porsi ruang yang lumayan besar bagi berita musik. Musik juga merupakan pembuka kemaksiatan lain. Orang yang suka musik mungkin akan sering menghadiri pertunjukan musik.

K. Mencontek

Perilaku yang ini biasa terjadi di sekolah, terutama saat ulangan atau ujian. Mencontek dilakukan untuk mendapatkan nilai yang bagus. Hakikatnya, mencontek adalah menipu, baik diri sendiri maupun guru. Hasil yang kamu peroleh mungkin memang seperti yang kamu harapkan. Tapi betulkah demikian kemampuanmu? Ingatlah, pertanggungjawaban nggak cuma didepan guru saja. Di akherat nanti, penipuan yang kamu lakukan tersebut juga harus kamu pertanggungjawabkan.

\section{Merokok}

Rokok seluruhnya mengandung racun. Bisa jadi ia malah lebih berbahaya daripada khamr. Kalau begitu, menghisap rokok juga tidak baik. Rokok juga merupakan pintu untuk merasakan hal-hal tidak baik lainnya. Rokok seluruhnya mengandung racun. Bisa jadi ia malah lebih berbahaya daripada khamr. Allah melarang kita membinasakan diri kita sendiri. Kalo begitu, menghisap rokok juga diharamkan. Pecandu rokok bisa tertarik untuk mencampurkan ganja di rokoknya. Ganja mempunyai efek memabukkan, jadi tentu saja ganja adalah barang haram. Kalau sudah kenal rokok-dan ganja tidak lama kemudian para remaja akan mencoba obat-obat penenang.

\section{Simpulan dan Saran}

Berdasarkan pembahasan yang telah dipaparkan kenakalan remaja meliputi semua perilaku yang menyimpang dari norma-norma hukum pidana yang dilakukan oleh remaja. Perilaku tersebut sangat merugikan dirinya sendiri dan orang-orang disekitarnya, terutama akan membuat orang tua merasa kecewa akan perbuatan yang telah dilakukan anaknya tersebut, karena merasa gagal dalam mendidik padahal orang tua telah berupaya medidiknya dengan baik. Kenakalan remaja pada zaman sekarang ini disebabkan oleh beberapa faktor. Perilaku nakal remaja disebabkan oleh faktor remaja itu sendiri (internal) maupun faktor dari luar (eksternal). Remaja harus bisa mendapatkan sebanyak mungkin orang-orang dewasa yang kiranya memotivasi perilaku yang baik dan juga orang yang telah berhasil memperbaiki diri setelah sebelumnya gagal pada tahap ini. Adanya motivasi dari keluarga, guru, teman sebaya merupakan hal-hal yang bisa dilakukan untuk mengatasi kenakalan remaja dan juga berpengaruh baik untuk perkembangan remaja. Anak-anak yang tidak disukai oleh teman-temannya anak tersebut menyendiri. Anak yang demikian akan dapat menyebabkan kegoncangan emosi. Seharusnya anak yang telah terjerumus dalam prilaku kenakalan remaja tidak dijauhi tetapi harus diberikan pembinaan dan pengawasan dari orang tua, dan pada dunia pendidikan juga seharusnya pihak sekolah harus memperketat dalam mendidik dan harus sering melakukan kerjasama dengan orang tua dari masing-masing siswa. Selain itu harus adanya tindakan-tindakan dari pemerintah untuk mengawasi tindakan remaja di Indonesia agar tidak terjerumus pada kenakalan remaja. Selanjutnya perlunya penanaman nilai moral, pendidikan dan nilai religius pada diri seorang remaja. Dengan demikian untuk meminimalisir kenakanalan remaja dari pihak keluarga, sekolah 
dan masyarakat dan pemerintah harus saling berpartisipasi agar remaja generasi penerus bangsa tidak mudah terpengaruh dan terjerumus dalam kenakalan remaja.

Berdasarkan hasil penelitian ini, peneliti mengharapkan adanya pemanfaatan penelitian ini dan seterusnya penelitian ini dapat menjadi bahan untuk melanjutkan penelitain seterusnya.

\section{Daftar Pustaka}

Eitzen, Stanlen D. 1986. Social Problems. Allyn and Bacon inc, Boston, Sydney, Toronto.

Paulus Hadisuprapto, Paulus.1997. Juvenile Deliquency Pemahaman dan Penanggulangannya, Jakarta: Citra Aditya Bakti.

Kartono, Kartini. 1993, Kenakalan Remaja. Jakarta: Rajawali Pers.

Soekanto, Soerjono . 1988. Sosiologi Penyimpangan. Jakarta: Rajawali.

Willis, S. 1994. Problema Remaja dan Pemecahannya. Penerbit Angkasa, Bandung

http://munabarakati.blogspot.co.id/2014/10/makalah-kenakalan-remaja.html

http://dbitio.blogspot.co.id/2012/11/kenakalan-remaja-dari-pandangan.html

http://helda.info/2009/06/kenakalan-remaja/

http://pusatremaja.com/2008/01/15/kenakalan-remaja/

http://yoyooh.com/original-post/yo-ori-remaja/90-kenakalan-remaja.html

http://www.scribd.com/doc/12007831/KENAKALAN-REMAJA

http://www.anneahira.com/narkoba/index.htm

http://pustaka.ut.ac.id/website/index.php?option=com_content\&view=article\&id=60:pkni4209kriminologi-dan-kenakalan-remaja\&catid=30:fkip\&Itemid=75

http://zonaclassic.blogspot.com/2008/04/dampak-siaran-tv-terhadap-kenakalan.html

http://psikonseling.blogspot.com/2010/02/pengertian-kenakalan-remaja.html

http://digilib.unnes.ac.id/gsdl/collect/skripsi/index/assoc/HASHa7c5.dir/doc.pdf

http://www.wikimu.com/News/DisplayNews.aspx?id=12915

http://subandowo.blogspot.com/2008/08/kenakalan-remaja.html

http://www.anneahira.com/narkoba/index.htm

https://ferli1982.wordpress.com/2012/01/26/kenakalan-remaja-dalam-bentuk-penyalahgunaannarkoba-di-wilayah-hukum-poltabes-palembang-suatu-perspektif-control-social-labelingdan-re-integrative-shaming-theory-2/

https://asrikoe.wordpress.com/2011/11/27/kenakalan-remaja-sebagai-perilaku-menyimpanghubungannya-dengan-keberfungsian-sosial-keluarga-kasus-di-pondok-pinang-pinggirankota-metropolitan-jakarta/

http://senandungawanrizal.blogspot.co.id/2011/11/sosiologi-terapankenakalan-remaja-studi.html 
https://ejournal.radenintan.ac.id/index.php/konseli 